\title{
Oncogene mutations in cancer and dysplasia associated with inflammatory bowel disease
}

\author{
J CHEN, BS, C-M CHAI, MD, W DALU, MD, L SHEN, MD, F FROMOWITZ, MD, \\ C COMPTON, MD, PHD, MV VIOLA, MD
}

\begin{abstract}
Chronic inflammatory bowel disease (IBD) predisposes affected individuals to the development of invasive colon cancer. Increased cancer risk has been seen in ulcerative colitis and Crohn's disease in Western societies as well as in schistosomal colitis in China. In this study it was found that the frequency of the 12 th codon of c-Ki-ras, as well as the specific amino acid substitutions, were similar in sporadic colon cancers, cancers associated with ulcerative colitis in the United States, and colon cancers found in patients with schistosomal colitis in Jiangsu province in China. Further, activating mutations of codon 12 of $\mathrm{e}-\mathrm{Ki}$-ras were found in high grade dysplastic lesions in chronic ulcerative colitis. The latter finding indicates that some dysplasias are clonal proliferative lesions with genetic characteristics associated with invasive cancer. Can J Gastroenterol 1990;4(7):384-389
\end{abstract}

Key Words: Carcinogenesis, Dysplasia, Oncogene, Ulcerative colitis

\section{Mutations oncogènes dans les cancers et la dysplasie associés} aux maladies inflammatoires de l'intestin

RESUME: Les maladies inflammatoires de l'intestin (MII) prédisposent les patients atteints au développement du cancer colique invasif. Dans les pays occidentaux, ce risque se manifeste dans la colite ulcéreuse et la maladie de Crohn; en Chine, il existe dans la colite à Schistosoma. La présente étude révèle que la fréquence de l'oncogène cellulaire $\mathrm{K}$-ras sur le chromosome 12 ainsi que des substitutions spécifiques d'acide aminé sont similaires dans les cancers sporadiques du côlon, lesquels sont associés à la colite ulcéreuse aux Etats-Unis et à la colite à Schistosoma dans la province chinoise de Jiangsu. Plus encore, l'activation de l'oncogène cellulaire $\mathrm{K}$-ras est à l'oeuvre dans les lésions dysplasiques de haut degré présentes dans la colite ulcéreuse chronique. Cette dernière observation indique que certaines dysplasie sont des lésions clonales prolifératives, dont les caractéristiques génétiques sont associées au cancer invasif.

Departments of Medicine and Pathology, State University of New York at Stony Brook, Stony Brook, New York, USA; Departments of Surgery and Pathology, Suzhou Medical College. Suzhou, Peoples Republic of China; Department of Pathology, Massachusetts General Hospital, Boston, Massachusetts, USA

Correspondence and reprints: Dr MV Viola, HSC-TL7, 080, State University of New York at Stony Brook, Stony Brook, NY 11794-8174, USA
T T HAS BEEN RECOGNIZED FOR MANY 1 years that patients with longstanding ulcerative colitis are at increased risk for developing invasive colon carcinoma. This association is most evident in patients with extensive disease of more than 10 years' duration (1-4). Population-based studies indicate that cancer risk is approximately 0.5 to $1 \%$ per year beginning 10 years after diag. nosis. Epithelial dysplasia is considered a precancerous lesion in ulcerative colitis and is used as a histologic predictor of cancer development (5). The relationship between dysplasia and cancer in ulcerative colitis has been inferred from the observation that colons resected for cancer in ulcerative colitis almost always have regions of associated dysplasia (6). Also, specimens resected because of dysplasia frequently harbour occult carcinomas (7). Because dysplasia may be difficult to distinguish from reparative changes in ulcerative colitis, a standardized classification has been developed and used to grade the severity of the dysplastic changes (8). It is presumed, but not unequivocally proven, that neoplastic transformation involves the progression of a colonic epithelial cell from normal morphology through increasing grades of dysplasia to invasive carcinoma, and that this process is associated with the accumulation of specific 
genetic lesions. Colectomy specimens from patients with chronic ulcerative colitis are an excellent resource to study the biology and genetics of the precancerous phase of colon cancer, since specimens often have carcinoma, varying grades of dysplasia and relatively normal or regenerative epithelium.

Cancer associated with inflammatory bowel disease (IBD) is of considerable importance in other regions of the world as well, particularly in southeastern China. Schistosoma japonicum infection is endemic in Jiangsu province and leads to a chronic schistosomal colitis. The colon cancer incidence rates in Jiangsu province, 44 cases per 100,000, are the highest in Asia. Dr Chen Ming-Chai and his colleagues $(9-12)$ have described the epidemiology and clinical aspects of schistosomal colitis in this region and presented the histologic evolution of inflammatory lesions progressing to invasive cancer. The histopathology of chronic schistosomal colitis is remarkably similar to that found in chronic ulcerative colitis and, in both disorders, flat dysplastic changes appear to be the precancerous lesion.

Invasive colon cancer is a genetically complex disease, evidenced by the finding of multiple karyotypic abnormalities and a high frequency of allelic loss at multiple chromosomal sites in colon cancer cells (13-16). Nevertheless, a series of nonrandom generic changes have been identified which occur frequently and appear to play a significant role in the molecular pathogenesis of this disease. These include alterations of dominantly acting oncogenes (ras, c-myc and c-src) and of presumed 'suppressor' genes located on chromosomes 5q, 17p and 18q.

Of the dominantly acting oncogenes, the ras genes have been studied in greatest detail, and approximately $50 \%$ of colon cancers have been found to have an oncogenic ras mutation $(17,18)$. The majority of mutations of ras genes in colon cancer occur at codon 12 or 13 of $\mathrm{c}-\mathrm{Ki}$-ras (approximately $90 \%$ ), the remainder occurring at codon 61 of $\mathrm{c}-\mathrm{Ki}$-ras and at similar positions in $\mathrm{N}$-ras. These mutations are associated with diminished GTPase ac- tivity and enhanced transforming properties of the $\mathrm{p} 21$ molecule in vitro.

pp $60^{c-s r c}$ tyrosyl kinase activity has been found to be increased, compared to normal colonic mucosa, in the majority of colon cancers, with some tumours demonstrating disproportionately high kinase activity compared to $\mathrm{pp} 60^{\mathrm{c}-\mathrm{src}}$ protein levels $(19-22)$. This has given rise to the notion that $\mathrm{pp} 60^{\mathrm{c}-\mathrm{src}}$ is 'activated' in colon cancer, as can be seen with the neural form of pp60 $60^{c-s r c}$, oncogenic mutations of c-src (eg, at positions 338, 378, 441, 527 of chicken $\mathrm{c}$-src, and 3) when a high proportion of $\mathrm{pp}^{\mathrm{c}} \mathrm{O}^{\mathrm{c}-\mathrm{src}}$ molecules are phosphorylated at Tyr 416 relative to Tyr 527. In previous studies the author was unable to detect activating mutations of $\mathrm{c}$-src in colon tumours expressing high levels of $p p 60^{c-s r c}$ kinase activity (23). The author's interpretation of these data is that colon cancer may represent the clonal expansion of a colonic epithelial cell at a specific stage in differentiation at which the cell normally expresses high levels of pp $60^{\mathrm{c}-s \mathrm{rc}}$ tyrosyl kinase, and this activity is not necessarily linked to cell transformation.

Both cytogenetic and molecular studies have shown that a portion or all of chromosomes 5, 17 and 18 are frequently lost in advanced colon carcinoma. This suggests that recessive genes on these chromosomes may be activated by loss of a normal balancing allele. A locus on $5 \mathrm{q}$ (APC) has been linked to familial adenomatous polyposis of the colon and has been mapped to $5 \mathrm{q} 2 \mathrm{l}-22(24,25)$. Nineteen to $36 \%$ of sporadic colon carcinomas have been reported to have hemizygous loss of $5 \mathrm{q}$ $(14,26-29)$. If genetic markers closely flanking the APC locus are used, approximately $50 \%$ of sporadic colon cancers will demonstrate loss of a portion of $5 \mathrm{q}$, indicating the importance of this locus in the molecular pathogenesis of sporadic colon cancer (30). A high incidence of allelic loss at chromosome $17 p$ has also been found in a number of studies of colon cancers (13-15). In a number of instances this has been associated with mutations of the $\mathrm{p} 53$ gene in the remaining allele (30-32). The described mutations occur in two evolutionary conserved regions of p53 and suggest that these mutations alter or inactivate the normal function of the gene product. Allelic loss at chromosome $18 \mathrm{q}$ occurs in approximately $75 \%$ of colon cancers, determined by karyotypic analysis and molecular studies $(11,27)$. A candidate 'suppressor' gene involved in the allelic deletion on $18 \mathrm{q}$ has recently been described (33). The gene on $18 \mathrm{q}$ shows sequence similarity to neural cell adhesion molecules and has been shown to have diminished expression as well as being mutated in a number of colon carcinomas.

The high frequency of specific genetic alterations in colon cancer allowed Vogelstein and his colleagues (27) to define the sequence of these genetic changes in the polyp to cancer sequence. They found that ras mutations and $5 \mathrm{q}$ deletions occurred with equal frequency in polyps and cancers but that $17 p$ and $18 q$ deletions occurred more frequently in invasive carcinomas. Their data suggest that the ras mutation and $5 \mathrm{q}$ deletion occur early in this sequence (but after the polyp has developed) and that the $17 \mathrm{p}$ and $18 \mathrm{q}$ deletions occur at the transition to, or after carcinoma has developed.

In this work, the author addresses a number of issues related to the role of oncogene mutations in cancers and dysplasias associated with IBD. First, the frequency and type of ras mutations in sporadic colon cancers (evolved from polyps) are determined and contrasted with colon cancers associated with IBD both ulcerative colitis in the United States and schistosomal colitis in China. Second, evidence is presented that the ras mutation may occur in the dysplastic phase of IBD.

\section{PATIENTS AND METHODS}

Tissue procurement: Resected colon specimens from American patients with sporadic colorectal cancer and ulcerative colitis were obtained at University Hospital and the Massachusetts General Hospital, in Boston, Massachusetts. Colectomy specimens from schistosomiasis patients with colon cancer were obtained from Kun San Hospital, Jiangsu province, 
People's Republic of China. Tumour specimens and samples of normal colonic mucosa were stored in liquid nitrogen until nucleic acids were extracted.

ras gene mutation analysis: Mutations at codons 12 and 13 of c-Ki-ras and $\mathrm{N}$-ras were scored by restriction fragment length polymorphisms of ras genes amplified in a polymerase chain reaction (PCR). The 5' end oligonucleotide primer used in the PCR was immediately adjacent to codon 12 or 13 and contained base mismatches compared to the wild-type sequence, which generated an artificial restriction site at codon 12 or 13 (34). Mutations were scored as a loss of the restriction site.

DNA extraction: Heavy molecular weight DNA was extracted from colon tumours or normal mucosa by homogenization in a solution containing sodium dodecyl sulphate $(0.1 \%)$ and proteinase $\mathrm{K}(200 \mathrm{mg} / \mathrm{mL})$ followed by multiple extractions with phenol/ chloroform as described previously (35).

Oligonucleotide primers and PCR: Primers were synthesized using a Cyclone DNA synthesizer (Millipore Corp) and purified by polyacrylamide gel electrophoresis. The primers used to score restriction fragment length polymorphism (RFLP) at codons 12 and 13 of c-K-ras and N-ras are noted below. The bases modified, with respect to the wild-type sequence, to create artificial restriction sites are underlined.

c-Ki-ras (codon 12): The $5^{\prime}$ end primer used generates a Bst $\mathrm{N} 1$ site at codon 12 . The 3' end primer contains an internal Bst $\mathrm{N} 1$ site (CCTGG).

\section{5 ' end primer:}

5' ACTGAATATAAACTTGTGGTAGTTG GACCT 3'

\section{3 ' end primer:}

5'TCAAAGAATGGTCCTGGAAC 3'

c-Ki-ras (codon 13): The modification of the $5^{\prime}$ end primer creates a BglI site at codon 13 to score mutations at that site. The 3' end primer used is that shown for the assay of codon 12 .

\section{5'primer:}

5'ACTGAATATAAACTTTGTGGTA GTTGGCCCTGGT 3'

$\mathrm{N}$-ras codon 12 and 13: The 5' end primer introduces a Bst $\mathrm{N} 1$ site to score

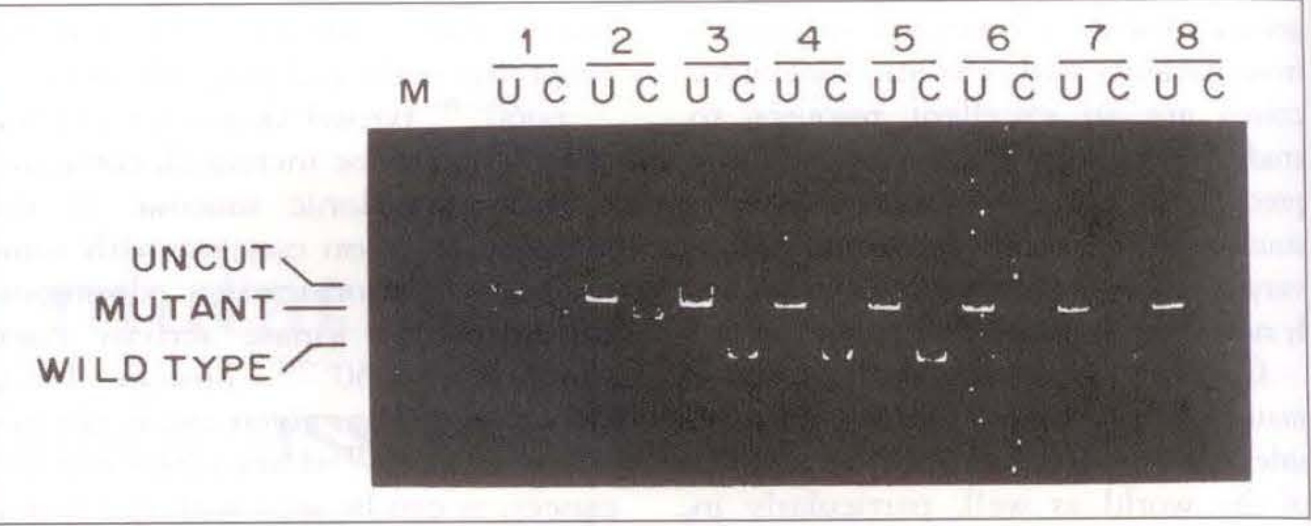

Figure 1) Restriction fragment length polymorphism assay for mutations of codon $12 \mathrm{c}$-Ki-ras. DNA from eight colon cancers were assayed and adjacent lanes represent polymerase chain reaction-amplified DNA which is uncut (U) or cut (C) with Bst N1. Four tumours (1, 2, 6 and 8) have a mutant band indicating a codon 12 mutation

mutations at codon 12 . The aspartic acid mutation of codon 13 ( $\mathrm{G}$ to $\mathrm{A}$ at position 2) creates an $H$ ph I recognition site. Therefore, this mutation which is the most common mutation of codon 13 , was scored by using primers as shown below for codon 12 followed by digestion with $\mathrm{Hph} \mathrm{I}$.

5' end primers:

5'ACTGAGTACAAACTGGTGGTGG TTGGACCA 3'

3 ' end primers:

5' GGGCCTCACCTCTATGGTGG 3'

DNA ( $1 \mathrm{mg}$ ) was added to $50 \mathrm{~mL}$ of PCR reaction mix containing $1 \mathrm{mM}$ dNTPs, $5 \mathrm{mM}$ Tris hydrochloride, $\mathrm{pH}$ 7.5, $75 \mathrm{mM}$ sodium chloride, $5 \mathrm{mM}$ magnesium chloride and $1 \mu \mathrm{g}$ oligomer primer. Two and one-half units of Taq I polymerase was added and the mixture overlaid with mineral oil. The DNA was amplified in a thermal cycler using the following conditions: denaturation $1 \mathrm{~min}$ at $95^{\circ} \mathrm{C}$; annealing $1 \mathrm{~min}$ at $55^{\circ} \mathrm{C}$; and elongation $1 \mathrm{~min}$ at $72^{\circ} \mathrm{C}$. The sample was subjected to 30 cycles of amplification, the oil removed and the reaction mixture extracted with chloroform. One-tenth of the reaction mix was added directly to the appropriate restriction enzyme buffer. Restriction enzyme was used at a ratio of five units enzyme per microgram of DNA, and digested for $2 \mathrm{~h}$. The digested products were subjected to electrophoresis in nondenaturing $8 \%$ polyacrylamide gels and analyzed after staining with ethidium bromide. In a number of instances the oligonucleotide primers were end labelled with $\left[{ }^{32} \mathrm{P}\right]-\mathrm{ATP}$ and polynucleotide kinase. Following amplification, enzyme digestion and electrophoresis, digestion products were analyzed by autoradiography.

DNA sequencing: Amplified DNA products were extracted with chloroform, diluted with $2.5 \mathrm{~mL}$ water and subjected to centrifuge-driven dialysis using a Centricon C-30 filter (Amicon, Massaschusetts), to remove excess primers. The double-stranded DNA was sequenced by the dideoxy-terminator method (36) using the $3^{\prime}$ end amplification primer and the modified T7 DNA polymerase, Sequenase (US Biochemicals, Ohio) as previously described (37).

\section{RESULTS}

Restriction fragment polymorphism assays were performed to detect mutations of codon 12 and 13 of $\mathrm{c}-\mathrm{Ki}$-ras and $\mathrm{N}$-ras in 42 sporadic colon cancers, 15 colon cancers associated with schistosomal colitis and three tumours associated with ulcerative colitis. The majority of mutations detected in the cancers in this study was at codon 12 of c-Ki-ras (Figure 1). These were scored using an artificially generated Bst N1 site at codon 12 using the PCR as described in the 'Patients and Methods' section. Twenty-three of 47 sporadic cancers, 12 of 15 colon cancers associated with schistosomiasis, and two of three cancers associated with ulcerative colitis were positive for ras mutations (Table 1). Eight of the mutations in cancers associated with schisto- 
TABLE 1

C-Ki-ras mutations in sporadic inflammatory bowel disease-associated colon cancers

\begin{tabular}{lcccc}
\hline Diagnosis & Positive/tested (\%) & Codon 12 & Codon 13 & $\begin{array}{c}\text { Amino acid } \\
\text { substitution }\end{array}$ \\
\hline $\begin{array}{c}\text { Sporadic colon } \\
\text { cancer }\end{array}$ & $23 / 47(49)$ & 23 & 0 & - \\
$\begin{array}{c}\text { Colon cancer } \\
\text { (schistosomiasis) }\end{array}$ & $12 / 15(80)$ & 11 & 1 & $\begin{array}{l}\text { 6-aspartate } \\
2 \text { - valine } \\
\text { Colon cancer } \\
\text { (ulcerative colitis) }\end{array}$ \\
\hline
\end{tabular}

TABLE 2

C-Ki-ras mutations in ulcerative colitis

\begin{tabular}{lcccc}
\hline Diagnosis & $\begin{array}{c}\text { Number of } \\
\text { patients }\end{array}$ & $\begin{array}{c}\text { Positive/ } \\
\text { tested }\end{array}$ & 12 & 13 \\
\hline $\begin{array}{l}\text { Normal colonic } \\
\text { mucosa }\end{array}$ & 14 & $0 / 14$ & - & - \\
$\begin{array}{l}\text { Ulcerative colitis } \\
\text { Inflammation }\end{array}$ & 9 & & - & - \\
High grade dysplasia & 1 & $0 / 37$ & Aspartate & - \\
& 1 & $2 / 5$ & ND & ND \\
& 1 & $2 / 2$ & - & ND \\
\hline
\end{tabular}

ND Not done

somiasis and one associated with ulcerative colitis were subjected to DNA sequencing of the PCR-generated ras amplification product. Of the schistosomiasis-associated cancers, six were found to have glycine to aspartate substitutions and two had glycine to valine substitutions. The one cancer found in an ulcerative colitis patient that was sequenced had a glycine to aspartate substitution.

The PCR-based assay was used for c-Ki- and $\mathrm{N}$-ras mutations to sample small biopsies of mucosa from patients with chronic ulcerative colitis (Table 2 ). No mutations were detected in multiple biopsies from ulcerative colitis that were negative for dysplasia. Two patients in this group were at increased risk for colorectal cancer as they had active ulcerative colitis for 10 and 20 years, respectively. However, samples from three of five patients with high grade dysplasia contained c-Ki-ras codon 12 mutations. Samples from one patient were sequenced and found to contain a glycine to aspartate mutation.

Multiple areas from two colectomy specimens were assayed which contained invasive cancer, areas of dysplasia and regions of inflammatory mucosa devoid of dysplasia. Multiple histologic sections were obtained to ensure that dysplastic areas were devoid of invasive carcinoma. In the study of the first specimen, an RNase protection assay was used on five contiguous samples of high grade dysplasia; those results were previously reported. Subsequent to that manuscript a carcinoma was found on the same specimen. RFLP analysis and DNA sequencing were performed on both cancer and dysplasia. Multiple RFLP assays were performed on the second specimen. In case 1 the invasive cancer and two contiguous regions of high grade dysplasia had a glycine to aspartate mutation of the $\mathrm{c}-\mathrm{Ki}$-ras codon 12 (Figure 2). In case 2, RFLP analysis demonstrated c$\mathrm{Ki}$-ras codon 12 mutations of the cancer and two regions of high grade dysplasia, but a normal c-Ki-ras gene was found in DNA from normal appearing mucosa distant from the tumour (Figure 2).

\section{DISCUSSION}

In this study the frequency of ras mutations in sporadic cancers (approximately $50 \%$ ) was similar to that found in a number of previous studies $(17,18)$. The authors were unable to obtain a sufficient number of samples of sporadic colon cancer from China to compare the mutation frequencies in sporadic cancers from China and the United States. The finding of 12 of 15

$(80 \%)$ schistosomiasis-associated colon

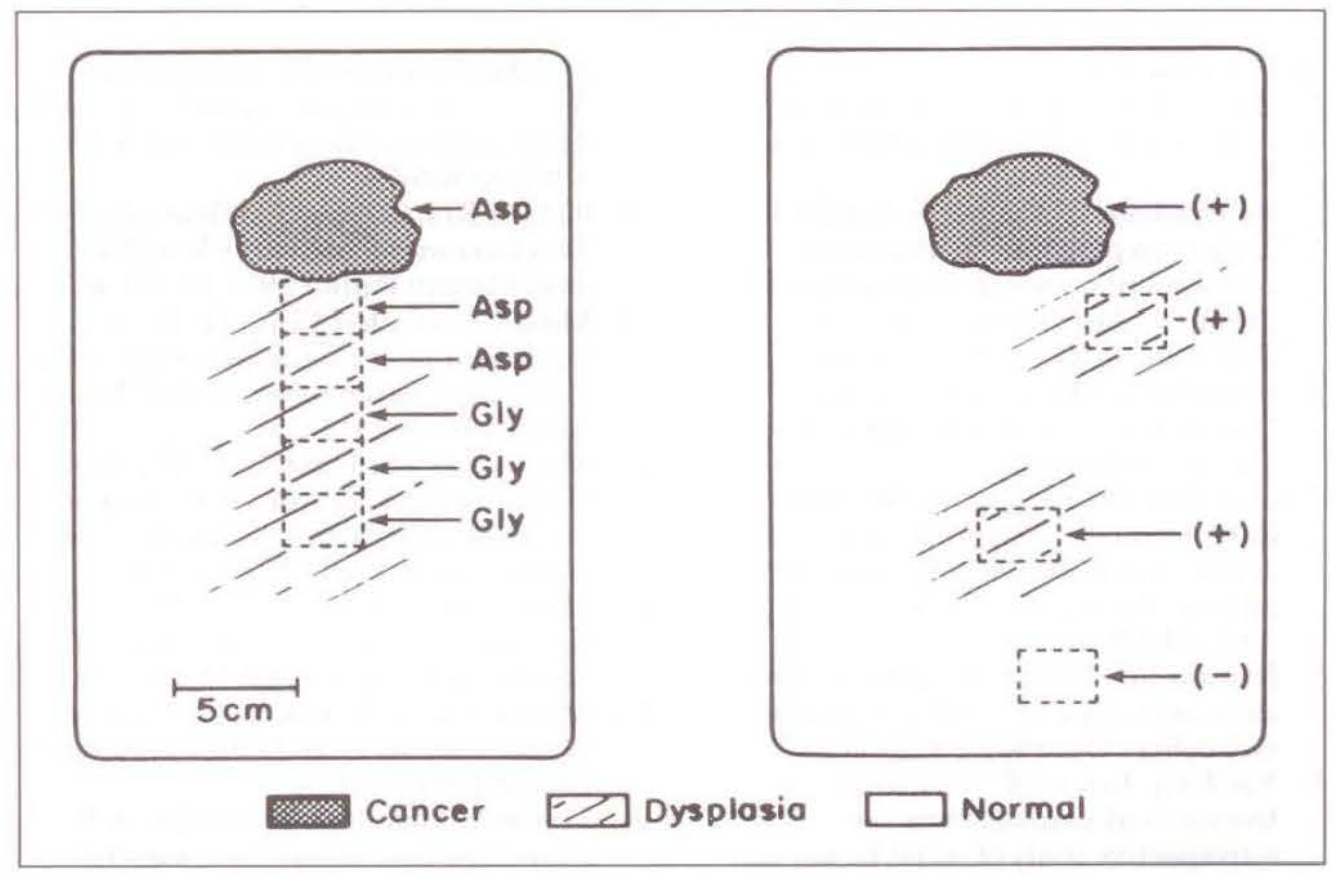

Figure 2) Results of $\mathrm{c}-\mathrm{Ki}$-ras of codon 12 mutation assays in colectomy specimens from patients with ulcerative colitis. In case 2 (right) (+) signifies the presence of a codon 12 mutation and ( $(-)$ indicates a wild type codon 12. Asp Aspartate; Gly Glycine 
cancers and two of three cancers in ulcerative colitis patients positive for ras mutations may represent a true higher incidence of mutation in this disease or more likely a selection bias in a small series. The assay of additional cancers associated with IBD will clarify this issue. The $\mathrm{c}-\mathrm{Ki}$-ras mutations were primarily of the 12 th codon and were either aspartate or valine substitutions for glycine. These are two frequent substitutions reported in sporadic cancers in the United States although serine and cystine mutations, which are also found in sporadic cancers, were not detected in these tumours.

Of interest was that four carcinomas had faint mutation bands in the RFLP assay on repeated analysis using ethidium staining or radioisotopically labelled oligonucleotide primers. The authors have examined the histologic sections immediately adjacent to the tissue assayed for mutations, and more than $80 \%$ of the cells were identified as tumour cells in all four tumours (data not shown). The lower limit of sensitivity of the RFLP assay is the detection of a mutation in approximately $5 \%$ of cells. It appears that the ras mutation was present in only a subpopulation of tumour cells, probably 5 to $10 \%$ of the cells. Therefore, it seems likely that the ras mutation occurred late in the evolu-

\section{REFERENCES}

1. Hinton JM. Risk of malignant change in ulcerative colitis. Gut 1968;7:427. 32.

2. Hendricksen C, Kreiner S, Bender V. Long term prognosis in ulcerative colitis based on results from a regional patient group from the county of Copenhagen. Gut 1985;26:158-63.

3. Kewenter J, Ahlman H, Hulten L. Cancer risk in extensive colitis. Ann Surg 1978;188:824-7.

4. Gyde SN, Prior P, Allan RW, Stevens D. Colorectal cancer in ulcerative colitis: A cohort study of primary referral from three centers. Gut 1988;29:206-17.

5. Morson BC, Pang, LSC. Rectal biopsy as an aid to cancer control in ulcerative colitis. Gut 1967;8:423-34.

6. Yardley ], Keren DF. 'Precancer' lesions in ulcerative colitis : A retrospective study of rectal biopsy and colectomy specimens. Cancer 1974; $34: 835-41$.

7. Blackstone MD, Riddell R, Rogers BH. tion of these cancers or, less likely, that the mutated allele was lost from a major population of tumour cells in the progression of the tumor. Other work has suggested that the ras mutation occurs early in most sporadic cancers, ie, in the adenoma stage (27).

The finding of activating $\mathrm{c}-\mathrm{Ki}$-ras mutations in high grade dysplasia is consistent with the finding of ras mutations in some polyps (27) and supports the notion that this mutation can frequently occur prior to the invasive stage of colon cancer development. The assay of additional specimens with low and intermediate grades of dysplasia will elucidate what the earliest stage in the transformation process is in which the ras mutation can be detected. Further, these studies will indicate whether activating mutations of ras will be a useful adjunct to histopathology in the assessment of cancer risk in chronic IBD.

In two instances the authors were able to score ras mutations in multiple samples throughout colectomy specimens from patients with ulcerative colitis with both cancer and dysplasia. It was found that dysplastic cells containing the identical mutation covered a wide area of mucosa, suggesting that dysplasia is not a focal lesion but rather it is a clonal, proliferative abnormality

Dysplasia associated lesion or mass detected by colonoscopy for long-standing ulcerative colitis. Gastroenterology 1981;80:366-74.

8. Riddell RH, Goldman H, Ransohoff D. Dysplasia in inflammatory bowel disease. Human Pathol 1983;14:931-66.

9. Ming-Chai C, Jen-Chun H, Pei-YC. Pathogenesis of carcinoma of the colon and rectum in schistosomiasis. Chinese Med J 1965;84:513-25.

10. Ming-Chai C, Shan-Chi C, Pei-Yu C. Granulamatous disease of the large intestine secondary to schistosome infection. Chinese Med J 1978;4:371-8.

11. Ming-Chai C, Chi-Yuan C, Pei-Yu C. Evolution of colorectal cancer in schistosomiasis. Cancer 1980;46:1661-75.

12. Ming-Chai C, Shan-Chi C, Pei-Yu C. Colorectal cancer and schistosomiasis. Lancet 1981;i:971-3.

13. Fearon E, Hamilton S, Vogelstein B. Clonal analysis of human colorectal tumors. Science 1987;238:193-7.

14. Law D, Olschwang S, Monpezat JP. Concerted nonsyntenic allelic loss in which spreads horizontally but is not vertically invasive. These data are supported by recent studies of cellular DNA content using flow cytometry and cytophotometric techniques demonstrating aneuploid clones of dysplastic epithelial cells in ulcerative colitis $(34,35)$. Further, it was found that there were regions of high grade dysplasia which lacked ras mutations even though they were contiguous to morphologically identical epithelium which scored positive in ras mutation assays. These data suggest that either the mutation occurs late in the evolution of the dysplastic clone or that there are multiple dysplastic clones in longstanding IBD. In two instances carcinoma contiguous to a region of dysplasia has been detected in which both cancer and dysplasia had the identical activating c-Ki-ras mutation. In these instances it is likely that the cancer evolved from the area of dysplasia.

In summary, these studies have shown that activating mutations of $\mathrm{c}$ $\mathrm{Ki}$-ras represent a common genetic pathway for transformation of colonic epithelial cells irrespective of etiology or ethnic background. Further, this genetic lesion can be found in the noninvasive stage in the evolution of colon carcinoma associated with IBD.

human colorectal cancer. Science 1988;241:961-5.

15. Vogelstein B, Fearon E. Allelotype of colorectal carcinomas. Science 1989;244:207-11.

16. Muleris M, Salmon R, Zafrani B. Consistent deficiency of chromosome 18 and the short arm of 17 in eleven cases of human large bowel cancer. Ann Genet 1985;28:206-13.

17. Bos J, Feron E. Prevalence of ras gene mutations in human colorectal cancers. Nature 1987;327:293-7.

18. Forrester K, Almoguera C, Han K, Grizzle W, Perucho M. Detection of high incidence of $\mathrm{K}$-ras oncogenes during human colon tumorigenesis. Nature 1987;327:298-303.

19. Bolen J, Veillette S, Schwartz A, DeSeau, V, Rosen N. Activation of pp $60^{c-s r c}$ protein kinase activity in human colon carcinoma. Proc Natl Acad Sci U S A 1987:84:2251-5.

20. Bolen J, Veillette A, Schwartz A. pp $60^{c-s r c}$ in human colon carcinoma and normal human colon mucosal 
cells. Oncogene Res 1987;1:149-68.

21. Cartwright C, Kamps M, Meisler A, Pysos J, Eckhart W. pp60 ${ }^{\text {c-src }}$ activation in human colon carcinorna. J Clin Invest 1989;83:2025-33.

22. Canwright C, Meisler A, Eckhart W. Activation of the pp $60^{\mathrm{c}-s r c}$ protein kinase is an early event in colonic carcinogenesis. Proc Natl Acad Sci USA 1990;87:558-62.

23. Wang P, Fromowitz F, Lynch S, et al. The carboxy terminal phosphorylation regulatory site of c-src is not mutated in human cancers with elevated pp $60^{c-s r c}$ activity. (In press)

24. Bodmer WF, Bailey CJ. Localization of the gene for familial adenomatous polyposis on chromsome 5 . Nature 1987;328:614-6.

25. Leppert M, Dobbs $M$. The gene for familial polyposis coli maps to the long arm of chromosome 5 . Science 1987;238:1411-3.

26. Solomon E, Voss R, Hall V, et al. Chromosome 5 allele loss in human colorectal carcinomas. Nature 1987;328:616-9.
27. Vogelstein B, Fearon E, Hamilton S. Genetic alterations during colorectal tumor development. N Engl J Med 1988;319:525-32.

28. Okamoto $M$, Sasaki $M$, Sugio $K$. Loss of heterozygosity in colon carcinoma from patients with familial polyposis coli. Nature 1988;331:273-7.

29. Rees M, Leigh SEA, Delhanty JDA, Jass JR. Chromosome 5 allele loss in familial and sporadic colorectal adenomas. $\mathrm{Br} \mathrm{J}$ Cancer 1989;59:361-5.

30. Ashton-Rickardt PG, Dunlop MG, Nakamura Y. High frequency of APC loss in sporadic colorectal carcinomas due to breaks clustered in 5 q21-22. Oncogene 1989;4:1169-74.

31. Baker S, Fearon E, Nigro J. Chromosome 17 deletions and p53 gene mutations in colorectal carcinomas. Science 1989;244:21 7-21.

32. Nigro J, Baker S, Preisinger A. Mutations in the $\mathrm{p} 53$ gene occur in diverse human tumor types. Nature 1989;342:705-8.
33. Fearon E, Cho K, Nigro J. Identification of a chromosome $18 \mathrm{q}$ gene that is altered in colorectal cancers. Science 1990;247:49-56.

34. Jiang W, Kahn S, Guillem J, Lu S, Weinstein B. Rapid detection of ras oncogenes in human tumors: Applications to colon, esophogeal and gastric cancer. Oncogene 1989;4:923-8.

35. Loughran A, Johnson B, Tierney J, Viola MV. Proto-oncogene structure in the cancer family syndrome. Cancer Genet Cytogenet 1989;38:75-82.

36. Sanger F, Niclen S, Coulsen AR. DNA sequencing with chain terminating inhibitors. Proc Natl Acad Sci USA 1977;74:5463-7.

37. Higuchi R, von Beroldingen $\mathrm{C}$, Sensobough GF, Erlich H. DNA typing from single hairs. Nature 1988;332:543-6.

38. Viola MV, Chen J, Fromowitz F, Finkel G, Compton C, Perucho M. ras mutations in precancerous cells in ulcerative colitis. In: Riddell R, ed. Dysplasia in Ulcerative Colitis. New York: Elsevier Press. (In press) 


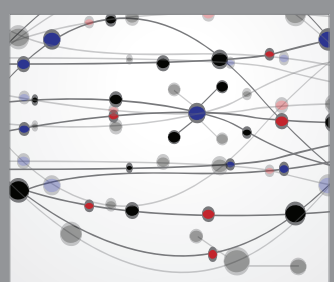

The Scientific World Journal
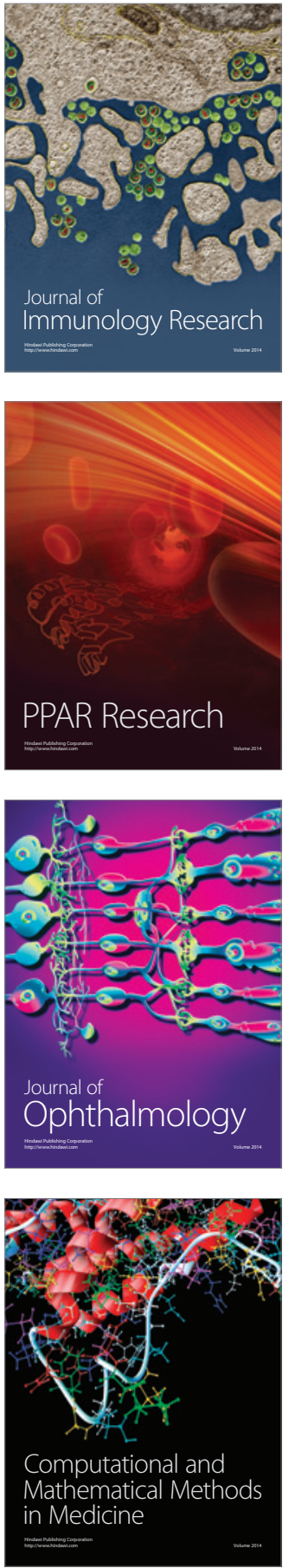

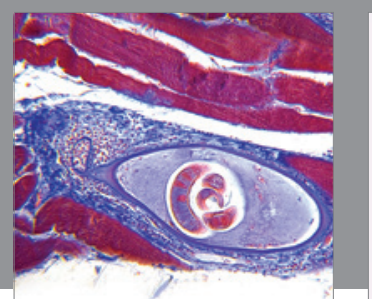

Gastroenterology Research and Practice

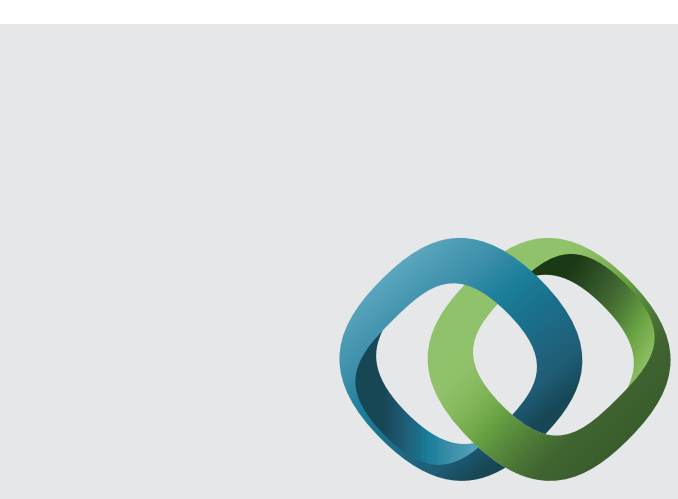

\section{Hindawi}

Submit your manuscripts at

http://www.hindawi.com
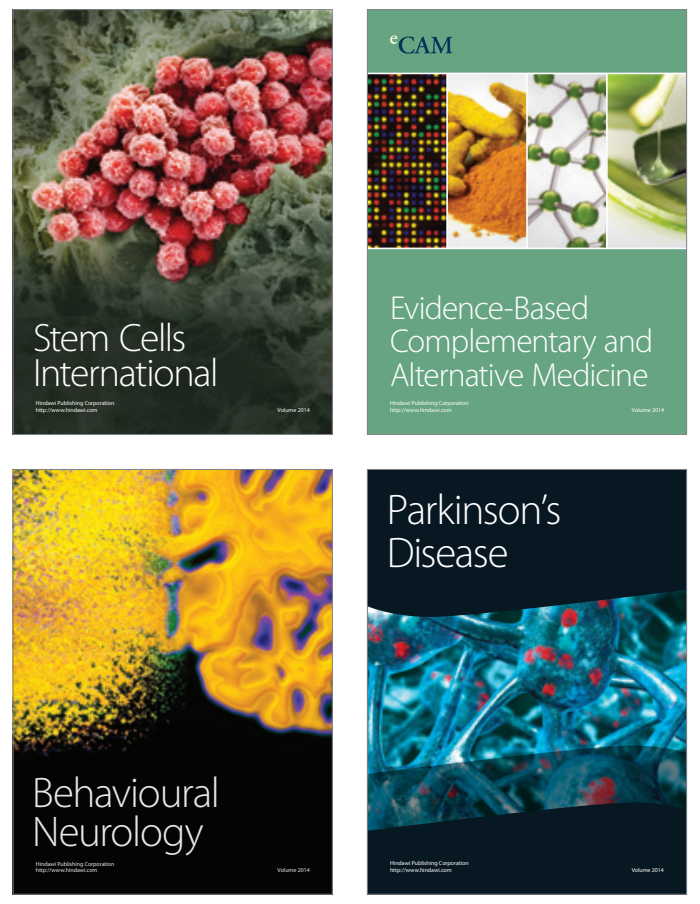
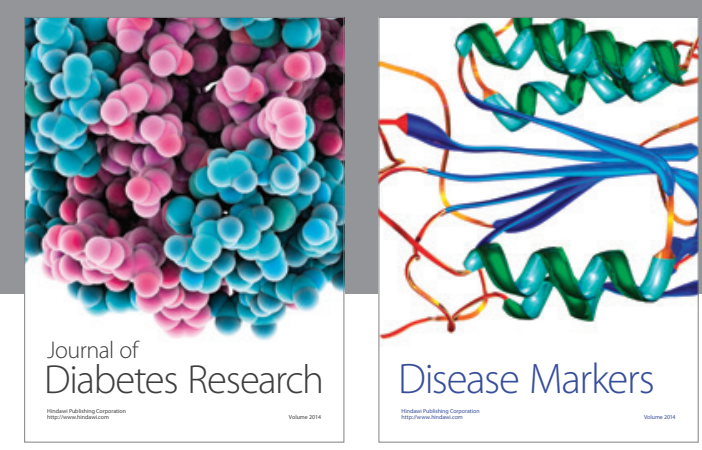

Disease Markers
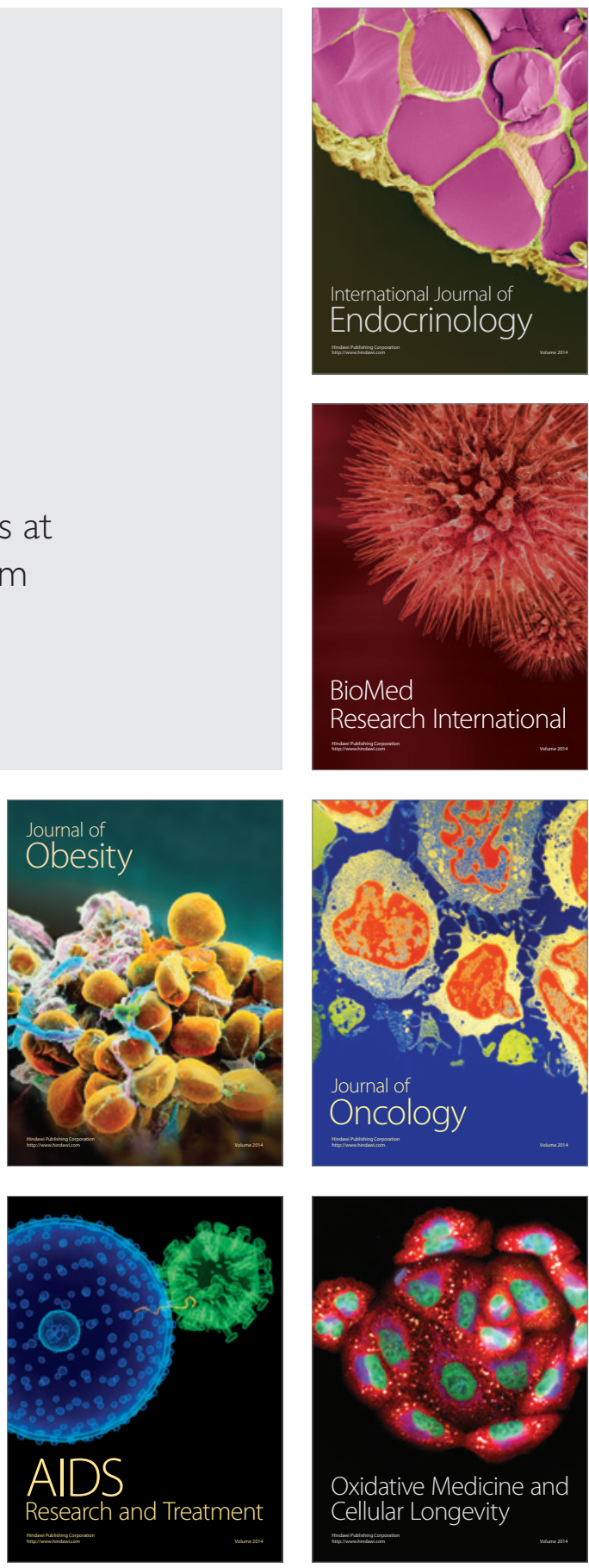